\title{
Problem ochrony interesu właściciela nieruchomości przy ustanawianiu służebności przesyłu
}

\begin{abstract}
\'dniu 30 maja 2008 roku Sejm RP uchwalił nowelizację kodeksu cywilnego, wprowadzającą do polskiego prawa służebność przesyłu․ Nowelizacja weszła w życie w tym samym roku, z dniem 3 sierpnia ${ }^{2}$. Instytucja służebności przesyłu uregulowana została we wprowadzonym w drugiej księdze kodeksu
\end{abstract}

\footnotetext{
* SŁawomir Patrycjusz Kursa - SWPS Uniwersytet Humanistycznospołeczny; e-mail: skursa@ swps.edu.pl.

${ }^{1} \mathrm{Na}$ temat służebności przesyłu zob. min. P. Gumiński, Urządzenia przesyłowe i służebność przesyłu, „Nieruchomości C.H. Beck” 8/2008, s. 13-18; E. Gniewek, Nowy rodzaj służebności - służebność przesyłu, „Acta Universitatis Wratislaviensis. Prawo” 308/2009, s. 137-156; J.M. Kondek, Stużebność przesyłu. Nowe ograniczone prawo rzeczowe, „Przegląd Sądowy” 3/2009, s. 23-27; P. Lewandowski, Jeszcze o stużebności przesyłu, „Monitor Prawniczy” 12/2009, s. 655-659; P. Lewandowski, Zagadnienia podmiotowe służebności przesyłu, „Państwo i Prawo” 6/2010, s. 80-91; M. Biernacki, Służebność przesyłu jako ograniczone prawo rzeczowe - kolaż prawniczy, „Rejent” 4/2010, s. 9-33; J. Pokrzywniak, Kluczowe dylematy związane z regulacja służebności przesyłu, „Rejent” 4/2010, s. 88-106; B. Załęska-Świątkiewicz, Stużebność przesyłu, „Rejent” 4/2010, s. 143-148; G. Bieniek, Założenia konstrukcyjne stużebności przesyłu de lege lata i de lege ferenda, (w:) Współczesne problemy prawa prywatnego. Ksiega pamiątkowa ku czci Profesora Edwarda Gniewka, Warszawa 2010, s. 9-18; Z. Gołba, Stużebności gruntowe, drogowe, osobiste i przesytu, Warszawa 2011, passim; M. Zalewski, Zasiedzenie służebności przesyłu - próba oceny zagadnień intertemporalnych, „Studia Iuridica Lublinensia" 16/2011, s. 279-303; B. Rakoczy, Stużebność przesyłu w praktyce, Warszawa 2012, passim; J. Luty, Nowy projekt Kodeksu cywilnego uzupełniający zagadnienia zwiąane z urządzeniami przesyłowymi oraz ze służebnościa przesyłu, „Rejent” 11/2012, s. 12 i n.; M. Zalewski, Posiadanie służebności przesyłu, „Annales UMCS” 1/2013, s. 135-146; P. Lewandowski, Służebność przesyłu w prawie polskim, Warszawa 2014, passim; M. Balwicka-Szczerba, Korzystanie z nieruchomości przez przedsiębiorców przesyłowych - właścicieli urządzeń przesyłowych, Warszawa 2015, passim.

${ }^{2}$ Jednocześnie ustawodawca nadał nowe brzmienie art. 49 (w dwóch paragrafach), określającemu dotąd status prawny urządzeń przesyłowych, a po przedmiotowej nowelizacji także uprawnienia dotyczące przeniesienia własności tych urządzeń.
} 
cywilnego, dziale trzecim „Prawa rzeczowe ograniczone”, tytule trzecim „Służebności”, rozdziale trzecim zatytułowanym „Służebność przesyłu”, w artykułach $305^{1}, 305^{2}$ (liczącym dwa paragrafy), $305^{3}$ (liczącym cztery paragrafy) i $305^{4}$. Do dnia dzisiejszego przepisy te nie zostały zmienione, mimo istnienia projektów ich nowelizacji.

Przedmiotem niniejszego artykułu jest spojrzenie na instytucję służebności przesyłu w obowiązującym kształcie i projekty jej nowelizacji, z punktu widzenia interesu właściciela nieruchomości, na której już się znajdują, bądź mają być posadowione urządzenia przesyłowe. Celem artykułu jest ustalenie, czy interes właściciela nieruchomości w takich przypadkach jest należycie chroniony prawem i czy byłby należycie chroniony w przypadku uwzględnienia zgłoszonych projektów nowelizacji obowiązujących w tym względzie przepisów.

\section{Kwestia interesu właściciela nieruchomości w projekcie z 2007 roku i w nowelizacji k.c. z 2008 roku}

Projekt nowelizacji wprowadzającej do kodeksu cywilnego służebność przesyłuª który stał się podstawą prac Sejmu VI kadencji ${ }^{4}$, przewidywał uprawnienie żądania ustanowienia służebności przesyłu tylko dla przedsiębiorcy przesyłowego. Uzasadnienie tego projektu jednoznacznie ukazywało cel, który przyświecał projektodawcy tej nowelizacji, jakim było zabezpieczenie interesu przedsiębiorców przesyłowych. W uzasadnieniu (s. 6) zaznaczono, że „służebność przesyłu może być zastosowana nie tylko do takich stanów faktycznych, w których urządzenia przesyłowe już istnieją, ale również do takich, w których przedsiębiorca urządzenia te zamierza wybudować w przyszłości, pozwoli zarówno na objęcie nową regulacją tzw. zaszłości, jak i da możliwość wykorzystania jej dla zabezpieczenia interesu prawnego przedsiębiorcy już $\mathrm{w}$ fazie planowania inwestycji”. Następnie w ocenie skutków regulacji (s. 16) wskazano, iż „zaproponowane w projekcie zmiany rozszerzające możliwość umownego kształtowania statusu prawnego urządzeń przesyłowych, a także wprowadzające nowy rodzaj służebności, niewątpliwie przyczynią się do poprawy warunków wykonywania działalności gospodarczej prowadzonej z wykorzystaniem takich urządzeń". Kilkunastostronicowe uzasadnienie tego projektu ani razu nie wspominało o interesie właściciela nieruchomości, ani prawnych środkach jego ochrony.

Wprowadzone do kodeksu cywilnego art. $305^{1}-305^{4}$ dowodzą, że rzeczony projekt nie został uchwalony w swoim pierwotnym sformułowaniu. W trakcie

\footnotetext{
${ }^{3}$ Druk nr 81 z dnia 6 listopada 2007 r.

${ }^{4}$ Projekt nowelizacji kodeksu cywilnego wprowadzającej służebność przesyłu był wcześniej przedmiotem prac Sejmu V kadencji, jednak nie zostały one ukończone przed jej upływem.
} 
prac legislacyjnych wprowadzono bowiem $\$ 2$ do projektowanego art. $305^{2}$, przyznający właścicielowi roszczenie o ustanowienie służebności przesyłu ${ }^{5}$.

Ustawodawca, zgodnie z projektem, zdefiniował służebność przesyłu $\mathrm{w}$ art. $305^{1}$ k.c., jako prawo przedsiębiorcy przesyłowego do korzystania w oznaczonym zakresie z nieruchomości obciążonej, zgodnie z przeznaczeniem urządzeń przesyłowych. Służebność ta może być ustanowiona na cudzej nieruchomości, tak będącej własnością podmiotów publicznych, jak i prywatnych, osób prawnych i osób fizycznych.

Zgodnie $\mathrm{z}$ art. $305^{2} \$ 1$ k.c., jeżeli ustanowienie służebności przesyłu jest konieczne dla właściwego korzystania z urządzeń przesyłowych, a właściciel nieruchomości odmawia zawarcia umowy z przedsiębiorcą, przedsiębiorcy przysługuje roszczenie o ustanowienie służebności przesyłu za odpowiednim wynagrodzeniem. Podobnie, w przypadku odmowy zawarcia umowy z właścicielem nieruchomości ze strony przedsiębiorcy przesyłowego, w myśl art. $305^{2}$ $\$ 2$ k.c., właścicielowi przysługuje roszczenie o odpowiednie wynagrodzenie w zamian za ustanowienie służebności przesyłu. W świetle tych przepisów ustanowienie służebności przesyłu wymaga albo zawarcia stosownej umowy ( $w$ formie aktu notarialnego) przedsiębiorcy z właścicielem nieruchomości, albo prawomocnego orzeczenia sądu o ustanowieniu służebności przesyłu za wynagrodzeniem. Należy oczywiście pamiętać, że na podstawie swobody umów (art. $353^{1}$ k.c.) możliwe jest zawarcie umowy przez przedsiębiorcę przesyłowego i właściciela nieruchomości o nieodpłatnym ustanowieniu służebności przesyłu.

$\mathrm{Z}$ treści obowiązujących przepisów wynika, że przedsiębiorca przesyłowy może wystąpić $\mathrm{z}$ wnioskiem o ustanowienie służebności przesyłu, tak w przypadku zamiaru wybudowania urządzeń przesyłowych na danej nieruchomości, jak i zamiaru uregulowania stanu prawnego urządzeń już posadowionych na cudzej nieruchomości, podczas gdy właścicielowi roszczenie takie przysługuje tylko w drugim przypadku. Takie rozwiązanie prawne, przyznające przedsiębiorcy przesyłowemu roszczenia $w$ dwóch różnych sytuacjach, nie budzi zastrzeżeń i nie oznacza braku równowagi między zabezpieczeniem interesu przedsiębiorcy przesyłowego i interesu właściciela nieruchomości, ponieważ trudno sobie wyobrazić, by właściciele nieruchomości kreowali politykę przedsiębiorstw przesyłowych i inicjowali ich działania w zakresie budowy nowych urządzeń na ich gruntach.

Należy zauważyć, że projekt nowelizacji kodeksu cywilnego z 2007 roku miał wyraźnie na względzie interes przedsiębiorców przesyłowych, i gdyby został uchwalony bez zmian, interes właścicieli nieruchomości, przez które przebiegają

${ }^{5}$ Poza wprowadzeniem $\$ 2$ do art. $305^{2}$ dokonano jedynie redakcyjnych zmian w art. $305^{2}$ (uchwalonym jako art. $305^{2} \S 1$ ) i art. $305^{3} \$ 3$. 
urządzenia przesyłowe, nie byłby należycie zabezpieczony ${ }^{6}$. Tylko bowiem od dobrej woli przedsiębiorcy przesyłowego zależałoby, czy dojdzie do legalizacji tzw. „Zaszłości” za odpowiednim wynagrodzeniem. Nie byłby on jednak zainteresowany takim odpłatnym uregulowaniem tego stanu prawnego, biorąc pod uwagę możliwość zasiedzenia służebności przesyłu, bez konieczności uiszczenia jakiegokolwiek wynagrodzenia właścicielowi. Sam właściciel nie miałby prawnej możliwości zmuszenia przedsiębiorcy przesyłowego do odpłatnego ustanowienia służebności przesyłu, co rodziłoby problem konstytucyjności tych przepisów. Wprowadzenie $\$ 2$ do art. $305^{2}$ uchroniło właścicieli nieruchomości, na których znajdują się urządzenia przesyłowe, przed nieprzemyślanym i stronniczym rozwiązaniem tej kwestii.

Tak więc w obowiązującym stanie prawnym przepisy określające roszczenia przedsiębiorcy przesyłowego i właściciela nieruchomości w zakresie ustanowienia odpłatnej służebności przesyłu są w tej kwestii należycie wyważone i uwzględniają interes obu stron.

\section{Kwestia interesu właściciela nieruchomości w projektach nowelizacji k.c. z 2010 i 2011 roku}

Po dwóch latach od wprowadzenia służebności przesyłu, pod koniec tej samej, VI kadencji Sejmu, Rząd przedstawił oryginalny i kontrowersyjny zarazem projekt zmiany przepisów kodeksu cywilnego normujących urządzenia przesyłowe i służebność przesyłu7. Projekt ten, zmieniony w zakresie regulacji dotyczącej wygaśnięcia służebności przesyłu oraz regulacji przejściowej odnoszącej się do zasiedzenia służebności przesyłu, został ponownie przedstawiony Sejmowi VII kadencji ${ }^{8}$. Projektodawca proponował, między innymi, dodanie $₫ 3$ do art. $305^{2}$ k.c., następującej treści: „Ustanowienie służebności przesyłu nastąpi $\mathrm{z}$ uwzględnieniem interesu społeczno-gospodarczego i uzasadnionego interesu właściciela nieruchomości, tak aby stanowiła jak najmniejsze obciążenie gruntów, na których urządzenia są lub mają być posadowione". Nominalnie tak sformułowany przepis wskazuje, że ustanowienie służebności miałoby następować z uwzględnieniem tak interesu przedsiębiorcy przesyłowego, który w swojej działalności realizuje cel publiczny ${ }^{9}$, jak i interesu właściciela nieruchomości.

\footnotetext{
${ }^{6}$ Por. P. Lewandowski, Stużebność przesyłu..., s. 14-15.

7 Druk nr 3595 z dnia 10 listopada 2010 r. Projekt ten bazował na projekcie z dnia 14 maja 2009 r., wypracowanym przez Komisję Kodyfikacyjną Prawa Cywilnego, którego tekst dostępny jest na: https://bip.ms.gov.pl/pl/dzialalnosc/komisje-kodyfikacyjne/komisja-kodyfikacyjna-prawa-cywilnego/.

${ }^{8}$ Druk nr $74 \mathrm{z}$ dnia 7 grudnia $2011 \mathrm{r}$.

${ }^{9} \mathrm{Na}$ ten temat zob. B. Sitek, Utilitas publica z perspektywy prawa rzymskiego i polskiego, „Themis Polska Nova" 1/2014, s. 27-30.
} 
Projekt tej nowelizacji zakładał jednocześnie daleko idące zmiany art. 49 k.c. Przewidziano, między innymi, rozszerzenie katalogu urządzeń przesyłowych wymienionych $\mathrm{w} \$ 1$ o ,urządzenia infrastruktury telekomunikacyjnej, a także urządzenia przeznaczone do prowadzenia ruchu kolejowego, urządzenia tras tramwajowych, transportu linowego, linii trolejbusowych". Biorąc pod uwagę specyfikę tego rodzaju urządzeń, bardzo czynny sposób korzystania z nich (przykładowo przejeżdżający przez prywatną nieruchomość pociąg, czy tramwaj), konieczność regularnych konserwacji i napraw, niosłyby one za sobą nieporównywalnie większy stopień uciążliwości ${ }^{10}$, niż urządzenia służące do doprowadzania lub odprowadzania płynów, pary, gazu, energii elektrycznej ${ }^{11}$. W praktyce właściciel nieruchomości, na której zostałaby ustanowiona pozwalająca na korzystanie z nich służebność przesyłu, byłby narażony na znaczne uciążliwości (przykładowo hałas, wibracje), a ponadto obecność przypadkowych osób na swojej nieruchomości. W efekcie na właścicielu nieruchomości spoczywałyby wszystkie obowiązki wynikające z tytułu własności, w szczególności płacenie podatku, choć $\mathrm{w}$ większym stopniu, niż w przypadku dotąd rozumianych urządzeń przesyłowych, ograniczone zostałyby jego uprawnienia. W tym kontekście trudno mówić, że przedmiotowa nowelizacja należycie ważyła interes przedsiębiorcy będącego właścicielem urządzeń przesyłowych $\mathrm{z}$ interesem właściciela nieruchomości, przez którą miałyby one przebiegaćc ${ }^{12}$.

Nie dziwi więc fakt, że propozycja tego rodzaju zmian spotkała się ze stanowczą krytyką Helsińskiej Fundacji Praw Człowieka, która w opinii z dnia 22 maja 2012 roku, przywołując wyrok Trybunału Konstytucyjnego z dnia 12 stycznia $2000 \mathrm{roku}^{13}$, słusznie podkreśliła, że „o ile umieszczenie urządzeń przesyłowych sensu stricte na nieruchomości nie powoduje nadmiernego ograniczenia prawa własności (odpowiada wymogom art. 64 ust. 3 i art. 31 ust. 3 Konstytucji), to zaproponowane rozwiązanie rozszerzenia służebności przesyłu budzi poważne wątpliwości konstytucyjne. Bez trudu można sobie wyobrazić sytuacje, w których przymusowe [...] ustanowienie służebności przesyłu w treści i formie proponowanej w projekcie ustawy będzie stanowiło nieproporcjonalną ingerencję $\mathrm{w}$ prawo własności, a nawet ukryte wywłaszczenie. Usytuowanie urządzeń przeznaczonych do prowadzenia ruchu kołowego, urządzeń tras tramwajowych, transportu linowego i linii trolejbusowych na nieruchomości służebnej niejednokrotnie doprowadzi do sytuacji, w której właściciel nieru-

${ }^{10}$ M. Bajor-Stachańczyk, P. Sobolewski, Opinia prawna o rządowym projekcie ustawy o zmianie ustawy - Kodeks cywilny, „Zeszyty Prawnicze Biura Analiz Sejmowych Kancelarii Sejmu” 3/2011, s. 165-166.

${ }_{11}$ Por. R. Trzaskowski, Opinia prawna do rzqdowego projektu ustawy o zmianie ustawy - Kodeks cywilny (druk nr 74), s. 6-9, do pobrania: http://przesył-energii.pl/prace-ustawodawcze/.

${ }_{12}$ M. Bajor-Stachańczyk, P. Sobolewski, Opinia prawna o rządowym projekcie..., s. 166.

${ }^{13}$ Sygn. P. 11/98, OTK ZU 1/2000, poz. 3. 
chomości nie będzie mógł z niej korzystać zgodnie ze społeczno-gospodarczym przeznaczeniem swego prawa”. W konkluzji stwierdziła, że projekt ten „W sposób niedostateczny wyraża interesy właścicieli nieruchomości oraz właścicieli urządzeń infrastruktury technicznej, a w szczególności po wejściu w życie może stać się w praktyce instrumentem, którego stosowanie będzie nosiło znamiona wywłaszczenia (naruszenia istoty własności) z obejściem konstytucyjnych przesłanek ekspropriacyjnych".

Wobec tak przekonującej krytyki projekt ten upadł na etapie prac legislacyjnych.

\section{Kwestia „odpowiedniego wynagrodzenia” za ustanowienie służebności przesyłu}

Przepisy art. $305^{2}$ k.c., jak wyżej wspomniano, w zakresie roszczenia przedsiębiorcy przesyłowego i właściciela nieruchomości o ustanowienie służebności przesyłu uwzględniają interes obu stron. Stwarzają one podstawę prawną do dochodzenia przez właściciela nieruchomości wynagrodzenia w zamian za jej ustanowienie $e^{14}$. Ustawodawca $\mathrm{w}$ art. $305^{2}$ posłużył się nieprecyzyjnym sformułowaniem „odpowiednie wynagrodzenie”, co w konsekwencji doprowadziło do rozbieżnej praktyki w zakresie ustalania jego wysokości.

Sąd Najwyższy w postanowieniu z dnia 27 lutego 2013 roku $^{15}$ stwierdził, że „brak w art. $305^{2} \$ 2$ k.c. kryteriów określenia rozmiaru wynagrodzenia oznacza, że ustawodawca pozostawił sądowi swobodę polegającą na indywidualizacji ocen w tym zakresie, formułowanych na podstawie określonego stanu faktycznego, które mogą także wynikać z ogólnych reguł porządku prawnego". W praktyce sądy przy określaniu wysokości wynagrodzenia, nie mając odpowiedniej wiedzy fachowej, są zmuszone do korzystania z opinii biegłych. Ci z kolei posiłkują się Krajowym Standardem Wyceny Specjalistycznym (KSWS).

Rada Krajowa Polskiej Federacji Stowarzyszeń Rzeczoznawców Majątkowych w dniu 8 grudnia 2014 roku uchwaliła i włączyła do zbioru Powszechnych Krajowych Zasad Wyceny (PKZW) „Standard specjalistyczny określania wartości służebności przesyłu oraz wynagrodzenia za bezumowne korzystanie z nieruchomości przez przedsiębiorców przesyłowych"16, jako zalecany do stosowania od 8 stycznia 2015 roku. W definicji pasa eksploatacyjnego urządzenia, jaką znajdujemy w tym standardzie (s. 4), stwierdzono iż, ma być on rozumiany

${ }^{14}$ Wynagrodzenie to w konstrukcji zbliżone jest do odszkodowań za szkody czysto majątkowe spowodowane obniżeniem wartości nieruchomości. Uwagi porównawcze w tym temacie zob. J.J. Szczerbowski, Szkoda czysto majątkowa w kontekście unifikacji prawa prywatnego w Europie, Olsztyn 2013, s. 79.

15 Sygn. IV CSK 440/12, LEX nr 1294169.

${ }^{16}$ https://pfsrm.pl/aktualnosci/item/14-standardy-do-pobrania. 
jako „powierzchnia części nieruchomości niezbędna dla korzystania przez przedsiębiorcę z urządzeń przesyłowych. Powierzchnię pasa eksploatacyjnego powinien określić przedsiębiorca stosownie do rzeczywistych potrzeb w powyższym zakresie". Warto podkreślić, że przede wszystkim od wielkości tej powierzchni miała zależeć wysokość wynagrodzenia, gdyż zgodnie z omawianym dokumentem (s. 4) pas służebności przesyłu „w każdym przypadku obejmuje pas eksploatacyjny”, a w zależności od okoliczności „może obejmować także strefę oddziaływania urządzenia oraz inne części nieruchomości, które utraciły w całości albo w części znaczenie dla właściciela lub użytkownika wieczystego w kontekście korzystania z nieruchomości zgodnie z jej przeznaczeniem". Tak więc, w myśl cytowanego standardu, to przedsiębiorca przesyłowy miał jednostronnie określać powierzchnię pasa eksploatacyjnego. To kuriozalne podejście, nie gwarantujące obiektywności, ani ochrony interesu właściciela nieruchomości, skutkowało określaniem przez przedsiębiorców przesyłowych pasa eksploatacyjnego na zaniżonym poziomie, celem zapłaty jak najniższego wynagrodzenia, na przykład określając szerokość pasa eksploatacyjnego jako szerokość przewodu wodociągowego plus $2 \mathrm{~cm}$.

W rozważaniach zawartych w uzasadnieniu uchwały z dnia 11 grudnia $2015 \mathrm{roku}^{17}$ Sąd Najwyższy stwierdził, że „powierzchnia nieruchomości zajęta pod służebność powinna odpowiadać warunkom eksploatacji sieci przyjętym w przedsiębiorstwie będącym właścicielem urządzeń przesyłowych. Wyznaczona w ten sposób strefa ma zabezpieczać potrzeby eksploatowania urządzeń, zapewniając przedsiębiorcy możliwość prawidłowego korzystania z nich, ale także ich konserwacji, naprawy, modernizacji, usuwania awarii, wymiany elementów, zgodnie $\mathrm{z}$ art. $305^{1}$ i $305^{2}$ k.c. Te okoliczności bierze zatem pod uwagę sąd ustanawiając służebność przesyłu”. Sąd Najwyższy wyraźnie podkreślił, że nie chodzi tylko o strefę eksploatacyjną.

Rada Krajowa Polskiej Federacji Stowarzyszeń w dniu 12 grudnia 2016 roku uchwaliła nowy „Standard specjalistyczny określania wartości służebności przesyłu i wynagrodzenia za jej ustanowienie oraz wynagrodzenia za bezumowne korzystanie $\mathrm{z}$ nieruchomości przez przedsiębiorców przesyłowy$\mathrm{ch}^{\text {"18 }}$, jako zalecany do stosowania od 1 stycznia 2017 roku. Standard ten nie operuje już pojęciem pasa eksploatacyjnego, ani tym bardziej nie przewiduje, że przedsiębiorca przemysłowy miałby określać powierzchnię pasa, od której zależy wysokość wynagrodzenia. Co równie ważne, w obecnie obowiązującym standardzie pas służebności przesyłu zdefiniowano (s. 4) jako „pas terenu niezbędny dla wykonywania przez przedsiębiorcę będącego właścicielem urządzeń

\footnotetext{
17 Sygn. III CZP 88/15, do pobrania: www.sn.pl/sites/orzecznictwo/Orzeczenia3/III\%20CZP\%20 88-15.pdf.

${ }^{18} \mathrm{https} / / / \mathrm{pfsrm} . \mathrm{pl} / \mathrm{aktualnosci} / \mathrm{item} / 14$-standardy-do-pobrania.
} 
wszystkich uprawnień objętych treścią służebności przesyłu”. Biorąc pod uwagę, że zwykle treść służebności przesyłu przewiduje nie tylko prawo do korzystania z niej przez przedsiębiorcę, ale także prawo do konserwacji, napraw, usuwania awarii, jak również modernizacji, takie zdefiniowanie pasa służebności przesyłu petryfikuje uchwałę Sądu Najwyższego z dnia 11 grudnia 2015 roku i daje pełniejszą ochronę interesu właściciela nieruchomości. Obliguje ono bowiem rzeczoznawcę każdorazowo do uwzględnienia i wycenienia w operacie szacunkowym pasa służebności przesyłu odpowiadającego wszystkim uprawnieniom przedsiębiorstwa przesyłowego, a więc zwykle nie wystarczy już przyjęcie szerokości urządzenia powiększonej o wspomniane wyżej $2 \mathrm{~cm}$.

Problemem wciąż pozostaje niejednolite podejście do kwestii szerokości pasa niezbędnego do wykonywania przez przedsiębiorców przesyłowych swoich uprawnień. Wydaje się, że najlepszym rozwiązaniem tego problemu byłoby wprowadzenie do art. $305^{2}$ przepisu blankietowego, na podstawie którego minister właściwy do spraw budownictwa, planowania i zagospodarowania przestrzennego oraz mieszkalnictwa $\mathrm{w}$ drodze rozporządzenia określiłby szerokość tego pasa, z uwzględnieniem rodzajów, specyfiki i parametrów urządzeń przesyłowych $^{19}$. Ułatwiłoby to niewątpliwie pracę tak rzeczoznawcom majątkowym, jak i sądom oraz ujednoliciłoby ich rozstrzygnięcia. Przedsiębiorcom przesyłowym i właścicielom nieruchomości, na których miałyby być ustanowione służebności przesyłu, stworzyłoby z kolei możliwość wstępnego, bardziej miarodajnego oszacowania potencjalnego wynagrodzenia i lepsze warunki wyjściowe do umownego ustanowienie służebności przesyłu. W konsekwencji $\mathrm{w}$ wielu przypadkach zapobiegłoby to czasochłonnym i kosztownym postępowaniom sądowym, zwłaszcza w przypadku często zdarzających się wygórowanych roszczeń ze strony właścicieli nieruchomości i zaniżanych kwot wynagrodzenia proponowanego przez przedsiębiorców przesyłowych.

\section{Literatura}

Bajor-Stachańczyk M., Sobolewski P., Opinia prawna o rzq̨dowym projekcie ustawy o zmianie ustawyKodeks cywilny, "Zeszyty Prawnicze Biura Analiz Sejmowych Kancelarii Sejmu” 3/2011, s. 163-174

Balwicka-Szczerba M., Korzystanie z nieruchomości przez przedsiębiorców przesyłowych - właścicieli urzadzeń przesyłowych, Warszawa 2015

Bieniek G., Założenia konstrukcyjne służebności przesyłu de lege lata i de lege ferenda, (w:) Współczesne problemy prawa prywatnego. Księga pamiątkowa ku czci Profesora Edwarda Gniewka, Warszawa 2010, s. 9-18

19 Por. propozycja wprowadzenia $\$ 4$ do art. 3052, dotyczącego „odpowiedniego wynagrodzenia”, zawarta w projektach rządowych z lat 2010-2011 (zob. przyp. 7 i 8); M. Bajor-Stachańczyk, P. Sobolewski, Opinia prawna o rzadowym projekcie..., s. 171; R. Trzaskowski, Opinia prawna... , s. 21-23. 
Biernacki M., Służebność przesyłu jako ograniczone prawo rzeczowe - kolaż prawniczy, "Rejent" 4/2010, s. 9-3

Gniewek E., Nowy rodzaj służebności - służebność przesyłu, „Acta Universitatis Wratislaviensis. Prawo" 308/2009, s. 137-156

Gołba Z., Służebności gruntowe, drogowe, osobiste i przesyłu, Warszawa 2011

Gumiński P., Urzązenia przesyłowe i służebność przesyłu, "Nieruchomości C.H. Beck" 8/2008, s. 13-18

Kondek J.M., Służebność przesyłu. Nowe ograniczone prawo rzeczowe, „Przegląd Sądowy” 3/2009, s. 23-27

Lewandowski P., Jeszcze o służebności przesyłu, „Monitor Prawniczy” 12/2009, s. 655-659

Lewandowski P., Służebność przesyłu w prawie polskim, Warszawa 2014

Lewandowski P., Zagadnienia podmiotowe służebności przesyłu, „Państwo i Prawo" 6/2010, s. 80-91

Luty J., Nowy projekt Kodeksu cywilnego uzupełniający zagadnienia zwiqzane z urządzeniami przesyłowymi oraz ze służebnością przesyłu, "Rejent” 11/2012, s. 12 i n.

Pokrzywniak J., Kluczowe dylematy zwiq̨zane z regulacją służebności przesyłu, "Rejent" 4/2010, s. 88-106

Rakoczy B., Służebność przesyłu w praktyce, Warszawa 2012

Sitek B, Utilitas publica z perspektywy prawa rzymskiego i polskiego, „Themis Polska Nova” 1/2014, s. 21-36

Szczerbowski J.J., Szkoda czysto majątkowa w kontekście unifikacji prawa prywatnego w Europie, Olsztyn 2013

Trzaskowski R., Opinia prawna do rzq̨dowego projektu ustawy o zmianie ustawy - Kodeks cywilny (druk nr 74), http://przesył-energii.pl/prace-ustawodawcze/

Zalewski M., Posiadanie służebności przesyłu, „Annales UMCS” 1/2013, s. 135-146

Zalewski M., Zasiedzenie służebności przesyłu - próba oceny zagadnień intertemporalnych, „Studia luridica Lublinensia" 16/2011, s. 279-303

Załęska-Świątkiewicz B., Służebność przesyłu, „Rejent” 4/2010, s. 143-148

\section{Streszczenie}

Artykuł zawiera ocenę ochrony prawnej interesu właściciela nieruchomości przy ustanawianiu służebności przesyłu według obowiązującej regulacji i w projektach nowelizacji dotyczących służebności przesyłu. Rozważa kwestię ustalania „odpowiedniego wynagrodzenia” za ustanowienie służebności przesyłu. Autor prezentuje wniosek de lege ferenda w postaci propozycji wprowadzenia przepisu blankietowego, na podstawie którego właściwy minister określiłby w drodze rozporządzenia szerokość pasa niezbędnego do wykonywania przez przedsiębiorców przesyłowych swoich uprawnień, z uwzględnieniem rodzajów, specyfiki i parametrów urządzeń przesyłowych, co prowadziłoby do ujednolicenia praktyki w tym względzie.

Słowa kluczowe: służebność przesyłu, przedsiębiorca przesyłowy, właściciel, odpowiednie wynagrodzenie, nieruchomość, nowelizacja. 


\section{The issue of protection of the property owner's interest in establishing of transmission servitude}

\section{Summary}

The article includes an evaluation of the legal protection of the interest of the property owner in establishing the servitude of the transmission according to the binding regulations and in the draft amendments to the servitude of transmission. Considers the issue of determining an "adequate remuneration" for establishing the servitude of transmission. The author presents a proposal de lege ferenda in the form of a proposal for a blanket regulation under which the competent minister would determine by regulation the width of the zone necessary for the transmission company to exercise its entitlements, taking into account the types, specifics and parameters of transmission devices, which would lead to the unification of practice in this regard.

Keywords: Transmission servitude, transmission company, owner, adequate remuneration, estate, amendment. 